\title{
Tropical ancient DNA from bulk archaeological fish bone reveals the subsistence practices of a historic coastal community in southwest Madagascar
}

Alicia Grealy ${ }^{1 *}$, Kristina Douglass ${ }^{2}$, James Haile ${ }^{3}$, Chriselle Bruwer ${ }^{4}$, Charlotte Gough $^{5}$, Michael Bunce ${ }^{1}$

${ }^{1}$ Trace and Environmental DNA (TrEnD) Laboratory, Department of Environment and Agriculture, Curtin University, Perth, WA 6102, Australia.

${ }^{2}$ Department of Anthropology, National Museum of Natural History, Smithsonian Institution, USA

${ }^{3}$ PalaeoBARN, Research Laboratory for Archaeology and the History of Art, Oxford University, UK

${ }^{4}$ Department of Anthropology and Archaeology, University of South Africa, Pretoria, South Africa, and Arc Maps and Graphics, Pretoria, South Africa

${ }^{5}$ Blue Ventures Conservation, London N7 9DP, UK

* Corresponding author. Trace and Environmental DNA Laboratory, Department of Environment and Agriculture, Curtin University, Perth, WA 6102, Australia. E-mail address: alicia.grealy@uqconnect.edu.au

Key words: ancient DNA, archaeology, biodiversity, bulk-bone, fish, Madagascar, metabarcoding, subsistence

\begin{abstract}
Taxonomic identification of archaeological fish bones provides important insights into the subsistence practices of ancient coastal peoples. However, it can be difficult to execute robust morphological identification of fish bones from species-rich fossil assemblages, especially from post-cranial material with few distinguishing features. Fragmentation, weathering and burning further impede taxonomic identification, resulting in large numbers of unidentifiable bones from archaeological sites. This limitation can be somewhat mitigated by taking an ancient DNA (aDNA) bulk-bone metabarcoding (BBM) approach to faunal identification, where DNA from nondiagnostic bone fragments is extracted and sequenced in parallel. However, a large proportion of fishing communities (both past and present) live in tropical regions that have sub-optimal conditions for long-term aDNA preservation. To date, the BBM method has never been applied to fish bones before, or to fossils excavated from an exposed context within a tropical climate. Here, we demonstrate that morphologically indistinct bulk fish bone from the tropics can be identified by sequencing aDNA extracted from 100-300 ya archaeological midden material in southwest Madagascar. Despite the biases of the approach, we rapidly obtained family, genus, and specieslevel assemblage information, and used this to describe a subset of the ichthyofauna exploited by an $18^{\text {th }}$ century fishing community. We identified 23 families of fish, including benthic, pelagic, and coral-dwelling fishes, suggesting a reliance on a variety of marine and brackish habitats. When possible, BBM should be used alongside osteological approaches to address the limitations of both; however, this
\end{abstract}


study highlights how genetic methods can nevertheless be a valuable tool for helping resolve faunal assemblages when morphological identification is hindered by taphonomic processes, lack of adequate comparative collections, and time constraints, and can provide a temporal perspective on fish biodiversity in the context of accelerated exploitation of the marine environment.

\section{Introduction}

The identification of archaeological fish bone offers important insights into the subsistence practices of ancient fishing communities. Fish are a staple food for coastal peoples throughout the world; modern estimates suggest that approximately $60 \%$ of the global population lives within $100 \mathrm{~km}$ of the coast (Erlandson and Rick 2008). As such, there is tremendous potential for archaeological data and interpretations to provide a long-term perspective that can inform present-day marine resource management and conservation policies (Braje 2010, Braje et al. 2015, Labrides and Weisler 2016, Speller et al. 2012). Fine-grained archaeological investigations of resource exploitation patterns are especially important because human arrival in many regions of the world has been correlated with an increase in faunal extinctions, implying that over-exploitation of local fauna has contributed to significant loss of biodiversity (Braje and Erlandson 2013). The coincidence of human colonisation and declines in floral and faunal diversity is particularly acute in island contexts (Rick et al. 2013). One example is Madagascar, which-although still considered a biodiversity 'hotspot' (Myers et al. 2000) - has undergone a significant loss of biodiversity over the last two thousand years that has long been thought to coincide with human arrival on the island (de la Bâthie 1921, Humbert 1927). However, many questions remain as to the timing of environmental change in Madagascar and the role early communities played in shaping the island's land and seascapes, particularly given the challenges of investigating early forager sites (Douglass and Zinke 2015). Furthermore, disentangling anthropogenic and climatic drivers of environmental change remains a central research concern in Madagascar, since the island's climate and environment were in constant flux well before human colonisation (Dewar and Richard 2007, Douglass and Zinke 2015). Moreover, despite the fact that Madagascar is an island, the historical ecology of Madagascar's marine and coastal environment has received little research attention. Instead, as is the case in other parts of the world (Erlandson and Rick 2008), far more archaeological and paleontological work has been directed at understanding anthropogenic impacts on terrestrial ecologies.

Determining how humans impacted the marine environment of Madagascar during the Holocene relies on a thorough understanding of the marine taxa that were targeted by ancient communities. Burnt or modified fish bone, or fish bones found in cultural deposits, are good gauges of direct human interaction with marine biota. As such, the identification of archaeological fish bone is essential to uncovering marine prey targets; to date, few studies comprehensively achieve this (Labrides and Weisler 2016), largely because of the limitations to morphological identification. The identification of fish bone predominantly relies on the examination of size range and diagnostic osteological features (Lambrides and Weisler 2015). Cranial elements, such as teeth, are particularly important in refining taxonomic identification. However, the cranium and teeth generally make up a small proportion of the overall number of bones recovered from archaeological deposits (Yang et al. 2004); for each cranium, there may be over three times as many post-cranial elements (Jones 2009), 
including vertebrae, ribs, spines, and rays. Articulated specimens are even rarer because fish remains are fragile and susceptible to damage during food preparation, cooking, and consumption, as well as to post-depositional weathering (Collins 2010). Vertebrae and ribs of many fish species are often difficult, if not impossible, to distinguish from one another as they display little variation between species (Teletchea 2009). To complicate matters further, many fish exhibit different morphology throughout their development from juvenile to adult, and can also display high intraspecific morphological variability, sexual dimorphism (Teletchea 2009), and phenotypic plasticity (Lambrides and Weisler 2015). Depositional bias, taphonomy, and lack of diagnostic features hinder morphological taxonomic identifications in many archaeological assemblages of fish bones, and often result in large numbers of unidentified remains.

Ancient DNA (aDNA) is a complementary method to the study of faunal remains, as it does not rely on the preservation of diagnostic morphological features. However, in Sub-Saharan African contexts, studies of archaeological aDNA are rare, despite the potential for aDNA analyses to complement traditional approaches to questions of human-environment interaction (Campana et al. 2013, Gifford-Gonzalez 2013). For fish, DNA reference collections represent a large portion of fish diversity, and DNA analysis has been used to discriminate cryptic species and morphotypes; for example, the genus Schindleria consists of 21 genetically distinct but morphologically cryptic species (Kon et al. 2007), while the morphologically different Eumicrotremus spinosus and E. eggvinii constitute a single species (Byrkjedal et al. 2007). Ancient DNA has also proved to be a useful tool in studies of archaeological fish assemblages (Campana et al. 2013), albeit in a relatively small number of studies (Teletchea 2009): in a literature search, only approximately $2.5 \%$ of articles published on archaeological aDNA relate to fish. However, the studies that have been published demonstrate the value of such an approach in garnering important information about species diversity and distribution in the past (Cannon and Yang 2006, Grier et al. 2013, Speller et al. 2005, 2013, Yang et al. 2004), and the economic importance of different fish taxa to ancient communities (Nikulina and Schmölcke 2015).

The infrequent use of aDNA techniques in the analysis of archaeological fish assemblages may be due to the fact that fish bones are often too small and numerous to warrant the high cost of individual DNA extraction and sequencing-especially in the tropics that have one of the highest biodiversities of fish in the world (Lambrides and Weisler 2015). Furthermore, the majority of fishing communities occupy 'exposed' sites in coastal tropical and sub-tropical zones, with a consistently hot climate that fluctuates annually between dry and humid. These landscapes often lack natural and permanent shelter formations (such as caves), and are not typically conducive to aDNA preservation. Nevertheless, aDNA has been retrieved from tropical zones before (e.g., Gutiérrez-García et al. 2014, Murray et al. 2012, Nicholls et al. 2003, Schroeder et al. 2015), including Madagascar (Kistler et al. 2014, Mitchell et al. 2014, Orlando et al. 2008), and the innovation of new methods promises to increase the successful application of aDNA analysis on materials collected in tropical localities.

The recently developed 'bulk-bone metabarcoding' (BBM) approach is one such method that allows the DNA from many bones to be extracted, amplified, and sequenced in parallel to rapidly and accurately identify many of the taxa within a sub- 

2013), which can increase the probability of characterising tropical archeofish remains. Here, we demonstrate how the BBM method can retrieve molecular that can then be used to examine past interactions of humans with their marine that can then be used to examine past interactions of humans with their marine environment.

\section{Materials and methods}

\subsection{Site description and dating}

The coastal 'Andamoty-be' archaeological site is located just north of the village of Andavadoaka (22 $\left.04^{\prime} \mathrm{S}, 43^{\circ} 14^{\prime} \mathrm{E}\right)$ in Toliara province, Southwest Madagascar (Figure 1a,b), and was excavated in June 2014 by K. Douglass. The site is bordered on the east by spiny forest and by the Mozambique Channel to the west. It is located within the Velondriake Marine Protected Area, a locally managed marine area (LMMA) that encompasses the longest continuous reef system in Madagascar and is protected under the International Union for Conservation of Nature (IUCN). A decade of reef and fisheries monitoring by Blue Ventures Conservation has generated an excellent modern record of marine biodiversity within Velondriake's shallow reef flats, sand flats, macro-algae, sea-grass and mangrove habitats (Cripps 2009, Cripps et al. 2015, Hantanirina and Benbow 2013, Harris et al. 2010, Jones et al. 2014, Nadon et al. 2007, Roy et al. 2009). Human occupation at the site is estimated to date between 100 and 300 ya based on the presence of imported $19^{\text {th }}$ century British stoneware ceramics and Venetian glass trade beads found in the accumulation. The site has been described in detail elsewhere (Douglass 2016).

Two replicate $2 \mathrm{~m} \times 2 \mathrm{~m}$ units were placed on areas with the highest density of surface scatter approximately $20 \mathrm{~m}$ apart and $500 \mathrm{~m}$ from the shoreline. Layers were excavated following the natural stratigraphy, resulting in four layers per unit with multiple sub-contexts within layers (Figure 1d). Excavated material was sieved onsite using $2 \mathrm{~mm} \times 2 \mathrm{~mm}$ mesh screens. Bones were subsequently sorted from cultural material and stored at room temperature. Gloves and facemasks were worn during excavation, sieving, and sorting to minimise contamination with modern DNA. Gloves did not come into contact with modern fish at any time during the excavation to ensure that no contamination by modern fish DNA was introduced to the samples during collection.

\subsection{Sample preparation}

Where possible, one pool of 50 bones (Figure 1c) was randomly generated for each context for a total of 13 pools (note that two contexts contained fewer than 50 bones; for these, all bones were pooled). Three additional pools of 50 bones were generated for the first layer in each unit ( 6 total) that targeted fish vertebrae fragments. A total of 887 bones were sampled, with each bone having an average mass of $123.5 \mathrm{mg}$. Approximately $20 \mathrm{mg}$ of bone was subsampled from each bone within a pool and these were ground into a fine powder using the Retsch PM200 Planetary Ball Mill at $500 \mathrm{rpm}$ for 5 minutes. Powder was stored at $-20^{\circ} \mathrm{C}$. All sample preparation was conducted in an isolated ultra-clean environment within Curtin University's TRACE 
A
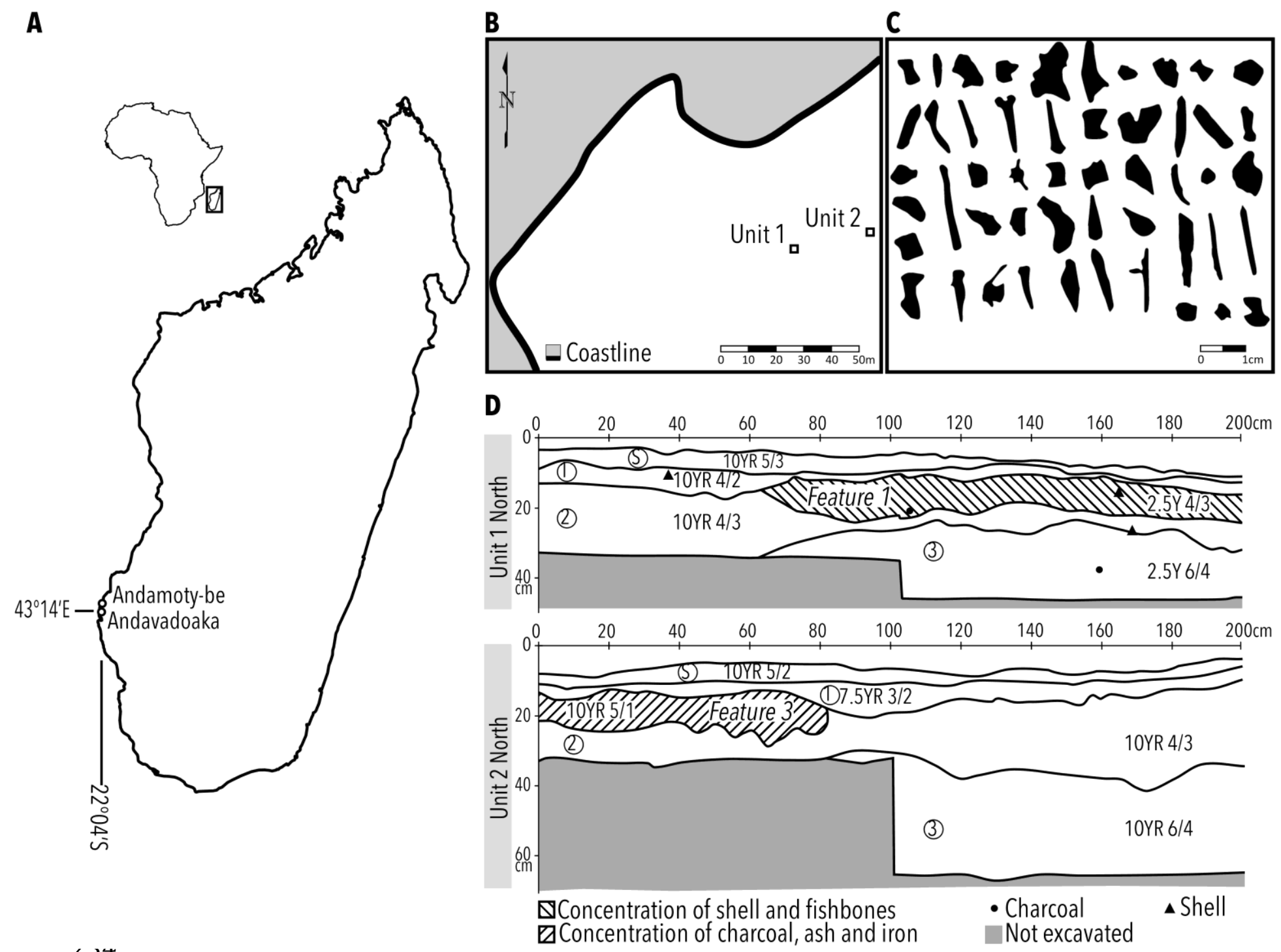

235

FIGURE 1 Map of Madagascar showing the location of $\mathbf{A}$ the archaeological site examined, and $\mathbf{B}$ placement of the excavation units; C Silhouettes of a representative pool of 50 bones as an example of the typical size and shape of bones from the archaeological accumulation; D North-wall profiles of the stratigraphy for each unit depicting the layers excavated (rendered by C. Bruwer; vertical axis represents depth). Note that these are examples of the stratigraphy and do not depict all contexts (for further detail refer to Douglass 2016). 
facility (WA, Australia) following standard aDNA protocols for contamination

\section{3 aDNA extraction}

aDNA was extracted from $100 \mathrm{mg}$ of bone powder for each pool, following the methods described by Grealy et al. (2016). DNA-free controls were included throughout the extraction processes and were carried through to sequencing.

\subsection{Metabarcoding and next-generation sequencing}

Primers targeting typical barcoding genes $\mathrm{CO} 1$ and $C y t b$ tend to amplify regions that are too long to capture degraded DNA fragments of ancient samples (Jordan et al. 2010). Therefore, aDNA extracts were amplified via qPCR using a primer set designed to target conserved regions of the fish $12 \mathrm{~S}$ rRNA mitochondrial gene. At $53^{\circ} \mathrm{C}$, these primers (12S 5'-CGCCTATATACCRCCGTC-3' and 5'CRCTACACCTCGACCTG-3', flanked by unique indexes and Illumina sequencing adapters) amplify a $56 \mathrm{bp}$ variable barcoding region from local members within more than 60 fish families. In silco analysis of the primer-binding sites shows that they are conserved across modern taxa found in the area, and are not likely to be inherently more biased towards the detection of any one taxon over another (SI 1.0, Figure S1). In most cases, the metabarcoding region differs by five or more base pairs between taxa of interest (Table S1), and it is unlikely that the combined effect DNA damage, amplification error, and sequencing error would result in taxonomic misidentifications (SI 1.0, Table S2). Amplification, subsequent sequencing on the MiSeq platform, trimming, and quality control were performed as per Grealy et al. (2016). DNA sequences are available on the online data repository Data Dryad and can be accessed via the doi:XXX_XXX

\subsection{Taxonomic assignment}

Taxonomy was assigned to sequences by comparison with NCBI's GenBank (Benson et al. 2006) nucleotide reference database using BLASTn (default parameters; Altschul et al. 1990) implemented through the Pawsey Supercomputing Centre (WA, Australia), and examination in MetaGenome Analyser (MEGAN v. 4.70.4; Huson et al. 2007) as per Grealy et al. (2016). Identifications were based on the similarity of query and reference sequence across $100 \%$ of the query, with similarity cut-offs for species-level IDs at $>98 \%$ similarity, genus-level IDs at $95-98 \%$ similarity, and family-level IDs at 90-95\% similarity. Assignments were assigned a credibility rating (highly credible, credible, or unlikely; Table 1) based on whether the taxa are found in area according to species' distribution records defined by FishBase (Froese and Pauly 2015), and whether genetic reference sequences exist in GenBank for all subtaxa within family or genus. 
TABLE 1 Molecular taxonomic identifications retrieved from analysis of bulk archaeological fish bone from six layers across two excavation units at Andamoty-be, Southwest Madagascar through next-generation sequencing of a short metabarcoding region of the mitochondrial 12SrRNA gene. Asterisks designate taxa not recorded in modern fisheries data. Grey cells indicate that the taxon was found in more than one sample (relevant to Layer 1 only). ^ Indicates that the taxon may be derived from modern contamination. Taxa are classified as being: $\$$ highly credible (within cut-off \%ID across $>100 \%$ of the query, found in area according to FishBase, with genetic reference sequences for all subtaxa within family or genus present in GenBank); $\uparrow$ credible (with in cut-off \%ID across $>100 \%$ of the query, but not all species of the genus or genus within the family that also occur in the area according to FishBase have reference sequences in GenBank); and $\Delta$ unlikely (within cut-off ID\% across $100 \%$ of the query, but not found in the area according to FishBase).

\begin{tabular}{|c|c|c|c|c|c|c|c|c|c|c|c|}
\hline & & & Layer & Surface & & & $\begin{array}{c}\text { Layer } \\
2\end{array}$ & $\begin{array}{l}\text { Layer } 2 \\
\text { Feature } 1\end{array}$ & $\begin{array}{c}\text { Layer } 2 \\
\text { Feature } 2\end{array}$ & $\begin{array}{c}\text { Layer } 2 \\
\text { Feature } 3\end{array}$ & $\begin{array}{c}\text { Layer } \\
3\end{array}$ \\
\hline & & & Unit & 12 & 1 & 2 & 12 & 12 & $\begin{array}{ll}1 & 2\end{array}$ & 2 & 12 \\
\hline $\begin{array}{l}\text { Family } \\
(90-94 \% \text { ID) }\end{array}$ & $\begin{array}{l}\text { Genus } \\
(95-97 \% \text { ID) }\end{array}$ & $\begin{array}{l}\text { Species } \\
(98-100 \% \text { ID) }\end{array}$ & $\begin{array}{l}\text { Common } \\
\text { name }\end{array}$ & & & & & & & & \\
\hline Dasyatidae & Himantura & gerrardi & $\begin{array}{l}\text { Whitespotted } \\
\text { whipray }\end{array}$ & & $\begin{array}{l}\ddagger \\
\ddagger\end{array}$ & & & & & & \\
\hline Latidae* & Psammoperca & waigiensis & $\begin{array}{l}\text { Waigeo } \\
\text { barramundi }\end{array}$ & & & $\begin{array}{l}\ddagger \\
\ddagger\end{array}$ & & & & & \\
\hline $\begin{array}{l}\text { Ginglymo- } \\
\text { stomatidae* }\end{array}$ & & & Nurse sharks & & & & & & & & $\ddagger$ \\
\hline Carcharhinidae & Carcharhinus & & $\begin{array}{l}\text { Requiem } \\
\text { sharks }\end{array}$ & & & $\ddagger$ & $\ddagger$ & & & & \\
\hline Mullidae & Mulloidichthys & & & & $\begin{array}{l}t \\
\ddagger\end{array}$ & & & & & & \\
\hline
\end{tabular}




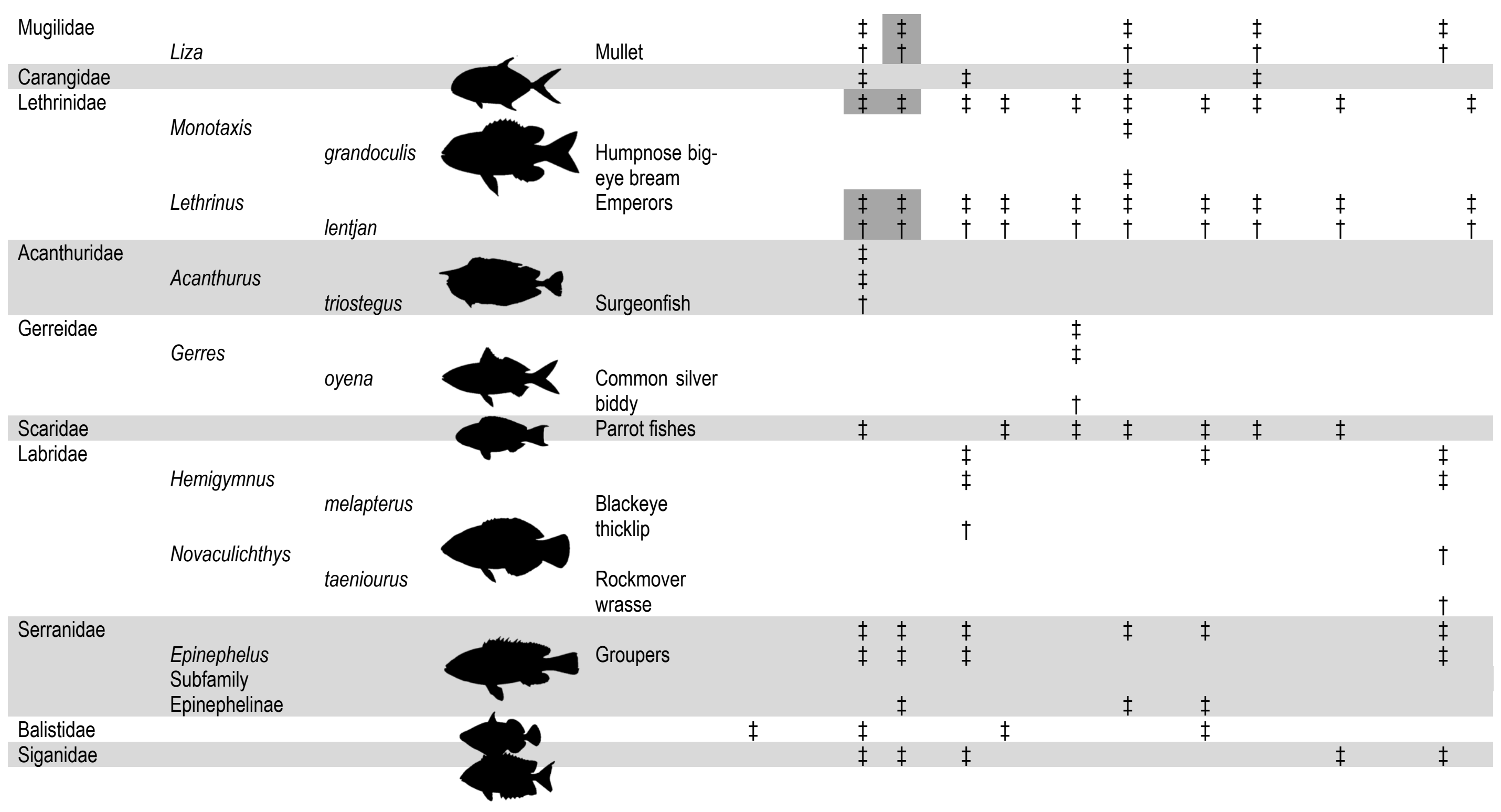




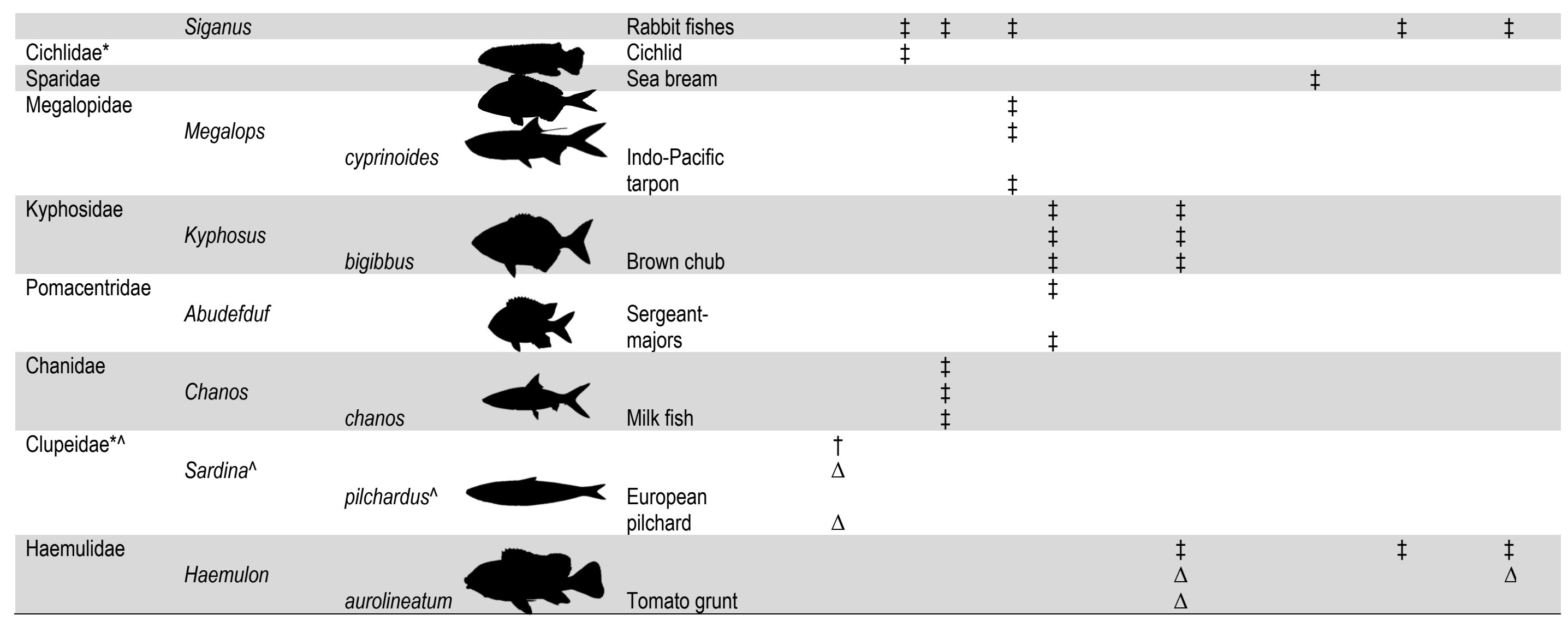




\section{Results and Discussion}

Next-generation sequencing of 56 bp 12S rRNA sequences amplified from bulk fish bone aDNA generated a total of 77,298 reads (an average of 4024 reads per pool) and 1338 unique reads (an average of 70 unique reads per pool). After molecular taxonomic identification by comparison with a reference database, 23 families were identified with high credibility; within them, 14 genera were able to be identified with high credibility, 4 credibly, and within those, 5 species were able to be identified with high credibility and 6 credibly (Table 1). No fish DNA was amplified in any of the controls, indicating that contamination from the laboratory environment was below detectable levels.

Despite the large diversity of taxa identified, habitat associations derived from modern fisheries data (Blue Ventures) suggest a primary reliance on near-shore reef-dwelling fish, with $53 \%$ of identified families associating with coral reefs, and the remainder associating with seagrass $(8 \%)$, mixed habitats $(11 \%)$, or unknown $(28 \%)$. These data suggest that there was a strong dependence on coral communities in terms of the exploitation of marine taxa. It appears that a range of fish sizes were targeted, and although not enough sampling has been done thus far to draw comparisons between layers, species within the family Lethrinidae (followed by Scaridae and Serranidae) were detected in more samples than any other taxa. This suggests that these typically large-bodied, high trophic-level fish may have constituted the primary staple marine food of people at Andamoty-be; in contrast, these families represent a small percentage of the catch in near-by Morombe today (Laroche et al. 1997). At Morombe, "high fishing pressure [has] led to a concentration of effort on lower trophic level species to maintain catch levels" (Laroche et al. 1997), an example of "fishing down marine food webs" (Pauly et al. 1998). This may indicate that fishing pressure in this region has increased over several hundred years, and that line fishing (the predominant method employed for catching high trophic-level fishes) may have been more commonly practiced by ancient communities than it is at present; today, only about $6 \%$ of catch in the Morombe region is by line (Laroche et al. 1997).

Other fish families detected include reef dwelling fish of the Chaetodontidae and Pomacentridae families (a mix of corallivores, planktivores, omnivores and herbivores, some of which are small and may have been used as bait fish), carnivores such as the wrasses of the Labridae family, members of the Carangidae family, and members of the Sparidae family. Megalops cyrinoides (Indo-Pacific tarpon) of the Megalopidae family are typically migratory fish that move between open water and inland rivers (Merrick and Schmida 1984). In the modern fisheries data (Blue Ventures), Megalopidae were recorded from catch in the coral habitat, suggesting that although adult fish could have been caught in the open sea beyond the barrier reef, they may have been netted, as adolescent $M$. cyprinoides migrate offshore from estuarine waters and mangroves (Coates 1987). Pelagic fish, like members of the Chanidae family (Chanos chanos, or milkfish), also possibly indicate open sea fishing; these fish live in large schools in surface waters over the continental shelf and generally require sophisticated fishing methods, including nets, larger outrigger canoes than are needed for fishing around coral reefs, and potentially the co-operation of several boats (Wheeler and Jones 1989). However, like members of the Megalopidae family, milkfish do migrate into brackish waters (including mangroves, estuaries, and lakes) as juveniles and return to the sea to sexually mature (Froese and Pauly 2015). Requiem sharks (Carcharhinus) are also known to occur in brackish and freshwater habitats. The presence of demersal fish such as the whitespotted whipray (Himantura gerrardi) may indicate the practice of bottom trawling or line fishing. In addition to serving as a food source, stingrays are commonly sought out in 
Velondriake today as a valuable source of abrasive material, and their tails are used as a tool to shape and sand wood (Douglass 2012).

Several taxa identified have not been recorded in modern fisheries data (Blue Ventures). These include carnivores such as Psammoperca waigiengsis (Waigeo barramundi) of the Latidae family and Ginglymostomatidae (nurse sharks), fresh-water fishes of the Cichlidae family, and forage-fishes of the Clupeidae family. The detection of nocturnal predators such as nurse shark and Waigeo barramundi may be an indication of night fishing, dive fishing, or leaving nets out overnight. In particular, nurse sharks are bottom feeders that live in shallow inshore waters with coral communities. Overfishing may be responsible for the rarity of these sharks today (Cooke 1997), indicating that there has been significant anthropogenic impact on the environment by past people. Furthermore, the "season of abundance" for sharks is predominantly April to July (Langley 2006), which may indicate that this site was inhabited during the cooler, dry season.

Detection of the Cichlidae family is interesting as this is the only non-marine family identified in the archaeological assemblage thus far, and no cichlid catch is recorded in the modern fisheries data (Blue Ventures). Cichlids are a diverse family, with 28 endemic and 9 introduced species known from Madagascar (Froese and Pauly 2015). This identification is strongly suggestive of fresh and/or brackish water fishing by local people. The closest occurrence of cichlid species to Andamoty-be is the Onilahy river basin's Ptychochromoides betsileanus and Ptychochromis onilahy: these species are classified by the IUCN as critically endangered and extinct (respectively) as a result of habitat loss, fishing, and competition or predation by introduced species. The Onilahy River is located approximately $180 \mathrm{~km}$ south of Andamoty-be, so the presence of a cichlid at Andamoty-be could be an indication that the ranges of one or both of these species extended as far as Andamoty-be in the past, but underwent a range contraction as a result of human pressures. With more research, a historic range could potentially be established for these species, which may inform conservation efforts (Hofman et al. 2015, Speller et al. 2012). To confirm the identification of cichlids, additional samples and metabarcoding genes should be sequenced.

Finally, the detection of Clupeidae DNA (100\% sequence similarity to Sardina pilchardus) in only the surface scatter layer is likely to have been derived from contamination by imported sardines: they are not native species but are a common component of human diet in Madagascar today. Although other sardine genera have been recorded in the modern fisheries data, these are generally well represented in genetic databases and their sequences differ from Sardina pilchardus by more than 9\%, making it unlikely that this DNA originated from native sardine species.

Like osteological approaches, not all taxa can be identified to the species-level, and some taxa are likely to have not been detected at all (c.f., Grealy et al. 2015 for an in-depth discussion of the biases and limitations of the method where a direct comparison with a morphological approach was possible): Table 1 shows that some taxa are not consistently detected between replicates, highlighting that the ability to detect a given taxon in a complex mixture can be variable. Similar to other metabarcoding approaches such as bacterial metagenomics or environmental DNA monitoring, this ability to identify taxa genetically is influenced by: (1) the intensity of sampling, (2) unique taphonomic biases that affect DNA preservation (including $\mathrm{pH}$, temperature fluctuations, and exposure to humidity), (3) collection and storage (such as handling that can introduce contamination), (4) choice of barcoding region (high intraspecific variation at a locus can affect taxonomic resolution), (5) 
incomplete reference genetic databases (while comprehensive, some taxa may not be represented), and (6) DNA damage, PCR bias, and sequencing error (although these can largely be mitigated by adequate sequencing depth, PCR replication, diluting inhibitors, and stringent quality control). Nevertheless, the detection of one taxon is not undermined by an inability to detect another, although we cannot confidently estimate what we did not find. In addition, although the amplification of longer fragments may have resulted in more refined taxonomic identifications, the degradation of aDNA in tropical environments typically results in the majority of fragments being very short; as such, there is a trade-off between the breadth of taxa identified and the specificity of identification (Grealy et al. 2015). Analysis of more samples, amplification of additional barcoding genes, and revisiting the existing data as genetic databases become more complete, will also deliver more fine-scaled molecular identifications and identify additional diversity. While not a complete audit of the past fish diversity, this is the first published description of an archaeological fish assemblage from southwest Madagascar, and demonstrates that a genetic approach provides useful zooarchaeological information in the absence of an alternative. The analysis of additional DNA extracts in the future will allow us to potentially compare archaeofish biodiversity between Andamoty-be and other archaeological sites in Madagascar.

\section{Conclusions}

This study has established the first published marine zooarchaeological record for Velondriake, offering insights into how past coastal communities derived a livelihood from local marine resources. This is particularly important to establish as accelerated rates of environmental degradation, resource over-exploitation and loss of faunal diversity in recent times have generated important concerns about the future of Madagascar's natural communities and the ability of human communities to derive sustainable livelihoods, especially in a region where more than a third of the population currently engage in sea fishing (Laroche et al. 1997). The data presented here provide a baseline upon which future data collection and analysis may build, and knowledge of historic biodiversity and human exploitation of the marine environment may assist in conservation and management decisions. Post-hoc comparisons with morphological analysis of fossil assemblages in Velondriake will confirm the accuracy (or otherwise) of the molecular identifications. Nevertheless, this study suggests that other archaeological sites around Madagascar, and in other tropical regions, may benefit from aDNA analysis of bulk bone to expand the taxonomic identifications obtained through traditional methods, and hopefully will encourage more fruitful collaborations between geneticists and archaeologists.

\section{Acknowledgements}

The archaeological investigations carried out in the Velondriake Marine Protected Area, were made possible with funding from the National Science Foundation Graduate Research Fellowship Program, the P.E.O. Scholar Award, the Yale Institute of Biospheric Studies, the Yale MacMillan Center for International and Area Studies and the Yale Council on Archaeological Studies. Research permissions were granted by the Ministère de 1'Enseignement Supérieur et de la Recherche Scientifique, Autorisation Numéro 128/13MESupReS/SG/DGRP and by the Centre de Documentation et de Recherche sur l'Art et les Traditions Orales Malgaches (CEDRATOM), under the auspices of the Memorandum of Understanding between the University of Toliara, under the direction of Dr. Barthélemy Manjakahery, Director of the CEDRATOM, and Yale University, under the direction of Dr. Roderick McIntosh, Professor of Anthropology. Local permission to carry out archaeological 
research was granted by the Office du Maire, Commune de Befandefa and by the Chefs de Fokontany of Andavadoaka, Nosy Ve, Antsaragnagnangy, Lamboara, Ampasilava and Salary. Permits for the export of archaeological materials for the purposes of laboratory analysis were granted by the Secretariat Général of the Ministère de l'Artisanat de la Culture et des Patrimoines, Direction Régionale de la Culture et du Patrimoine Atsimo Andrefana, Visas de Sorties Numéro 09/06-MCP/SG/DRCP.AA; Numéro 05/14-MACP/SG/DRCP.AA; Numéro 08/14-MACP/SG/DRCP.AA in accordance with Avis Numéro 375, 02/02/1978. We acknowledge the support of the Australian Research Council Discovery Project grant DP160104473 (MB).

We give special thanks to the Morombe Archaeological Project (MAP) team, to the people of Andavadoake, Madagascar, and to Blue Ventures conservation for sharing data pertaining to modern Velondriake Fisheries. We would also like to thank James Taylor for his assistance with sample preparation and sequencing, and Joey DiBattista for offering insights into fish behavior. High-throughput BLAST searches were performed through the Pawsey Supercomputing Centre (Perth).

\section{Author contributions}

KD organised and directed the archaeological excavation. AG and $\mathrm{JH}$ assisted with the collection of bulk bone material. AG conducted genetic analyses with assistance from MB. JH designed the primers used. CG provided modern fisheries data for comparison. CB rendered the line drawings and figure. $\mathrm{AG}$ and $\mathrm{KD}$ drafted the manuscript with contributions and edits from all co-authors.

\section{References}

Altschul SF, Gish W, Miller W et al. (1990) Basic local alignment search tool. Journal of Molecular Biology 215: 403-410.

Benson DA, Karsch-Mizrachi I, Lipman DJ et al. (2006) Gen-Bank. Nucleic Acids Research 34: D16eD20.

Braje TJ (2010) Modern oceans, ancient sites: archaeology and marine conservation on San Miguel Island, California. Salt Lake City, University of Utah Press.

Braje TJ and Erlandson (2013) Human acceleration of animal and plant extinctions: a Late Pleistocene, Holocene and Anthropocene continuum. Anthropocene 4: 14-23.

Braje TJ, Rick TC, Erlandson JM, Rogers-Bennett L, Catton CA (2015) Historical ecology can inform restoration site selection: the case of black abalone (Haliotis cracherodii) along California's Channel Islands. Aquatic Conservation: Marine and Freshwater Ecosystems.

Byrkjedal I, Rees DJ, Willassen E (2007) Lumping lumpsuckers: molecular and morphological insights into the taxonomic status of Eumicrotremus spinosus (Fabricius, 1776) and Eumicrotremus eggvinii (Koefoed, 1956) (Teleostei: Cyclopteridae). Journal of Fish Biology 71: 111-131. 
Campana MG, Bower MA, Crabtree PJ (2013) Ancient DNA for the archaeologist: the future of African research. African Archaeological Review 30: 21-37.

Cannon A and Yang DY (2006) Early storage and sedentism on the Pacific Northwest Coast: ancient DNA analysis of salmon remains from Namu, British Columbia. American Antiquity 71: 123-140.

Coates D (1987) Observations on the biology of tarpon, Megalops cyprinoides (Broussonet) (Pisces: Megalopidae), in the Sepik River, Northern Papua New Guinea. Australian Journal of Marine and Freshwater Research 38: 529-535.

Collins BR (2010) Element survivability of Salmo salar. Journal of Taphonomy 8: 291-300.

Cooke AJ (1997) Survey of Elasmobranch fisheries and trade in Madagascar in The trade shark and shark products in the western Indian and southeast Atlantic oceans, Marshall NT and Barnett R (eds.). Graphicor: South Africa.

Cripps G (2009) Understanding migration amongst the traditional fishers of West Madagascar. Blue Ventures Conservation Report for ReCoMaP.

Cripps G, Harris A, Humber F, Harding S, Thomas T (2015) A preliminary value chain analysis of shark fisheries in Madagascar. Indian Ocean Commission SF/2-15/34.

De la Bâthie HP (1921) La végétation malgache. Annales du Musée Colonial de Marseille 9: $1-266$.

Dewar RE and Richard AF (2007) Evolution in the hypervariable environment of Madagascar. Proceedings of the National Academy of Sciences of the United States of America 104: 13723-13727.

Douglass S (2012) Fisher's of a song: community music education in Andavadoaka, Madagascar. A thesis presented to the Faculty of the Steinhardt School of Culture, Education and Human Development at New York University in Candidacy for the Degree of Master of Arts in Music Education.

Douglass $\mathrm{K}$ and Zinke J (2015) Forging ahead by land and by sea: archaeology and paleoclimate reconstruction in Madagascar. African Archaeological Review 32: 267-299.

Douglass K (2016) An archaeological investigation of settlement and resource exploitation patterns in the Velondriake Marine Protected Area, Southwest Madagascar, ca. 900 BC to AD 1900. A dissertation presented to the Faculty of the Graduate School of Yale University in Candidacy for the Degree of Doctor of Philosophy.

Erlandson JM and Rick TC (2008) Archaeology, marine ecology, and human impacts on marine environments. University of California Press; Berkeley 1-19.

Froese R and Pauly D (2015) FishBase. Available: wwww.fishbase.org. Accessed: Jul 2015.

Gifford-Gonzalex D (2013) Animal genetics and African archaeology: why it matters. African Archaeological Review 30: 1-20. 

traditional palaeontological methods. Quaternary Science Reviews 128: 37-47.

Grealy A, Macken A, Allentoft ME, Rawlence NJ, Reed E, Bunce M (2016) An assessment of ancient DNA preservation in Holocene-Pleistocene fossil bone excavated from the world heritage Naracoorte Caves, South Australia. Journal of Quaternary Science 9999: $1-13$.

Grier C, Flanigan K, Winters M, Jordan LG, Lukowski S, Kemp BM (2013) Using ancient DNA identification and osteometric measures of archaeological Pacific salmon vertebrae for reconstructing salmon fisheries and site seasonality at Dionisio Point, British Columbia. Journal of Archaeological Science 40: 544-555.

Gutiérrez-García TA, Vázquez-Domínguez E, Arroyo-Cabrales J, Kuch M, Enk J, King C, Poinar HN (2014) Ancient DNA and the tropics: a rodent's tale. Biology Letters 10: 20140224.

Hantanirina JMO and Benbow S (2013) Diversity and coverage of seagrass ecosystems in south-west Madagascar. African Journal of Marine Science 35: 291-297.

Haouchar D, Haile J, McDowell MC, Murray DC, White NE, Allcock RJN, Phillips MJ, Prideaux GJ, Bunce M. 2014. Thorough assessment of DNA preservation from fossil bone and sediments exavated from a late Pleistocene-Holocene cave deposit on Kangaroo Island, South Australia. Quaternary Science Reviews 84: 56-64.

Harris A, Manahira G, Sheppard A, Gough C, Sheppard C (2010) Demise of Madagascar's once great barrier reef: change in coral reed condition over 40 years. Atoll Research Bulletin 574:1-16.

Hofman CA, Rick TC, Fleischer RC, Maldonado JE (2015) Conservation archaeogenomics: ancient DNA and biodiversity in the Anthropocene. Trends in Ecology and Evolution 30: $540-549$.

Humbert H (1927) La Destruction D'une Flore Insulaire Par Le Feu. Principaux Aspects de la Végétation À Madagascar. Documents Photographiques Et Notices. Mémoires de I'Académie Malgache 5: 1-80.

Huson DH, Auch AF, Qi J, et al. (2007) MEGAN analysis of metagenomic data. Genome Research 17: 377e386.

Jones S (2009) Food and gender in Fiji: ethnoarchaeological explorations. Lexington Books; USA.

Jones T, Ratsimba H, Ravaorinorotsihoarana L, Cripps G, Bey A (2014) Ecological variability and carbon stock estimates of mangrove ecosystems in Northwestern Madagascar. Forests 5: 177-205. 
Jordan LG, Steele CA, Thorgaard GH (2010) Universal mtDNA primers for species identification of degraded bony fish samples. Molecular Ecology Resources 10: 225-228.

Kistler L, Ratan A, Godfrey LR, Crowley BE, Hughes CE, Lei R, Cui Y, Wood ML, Muldoon KM, Andriamialison H, McGraw JJ, Tomsho LP, Schuster SC, Miller W, Louis EE, Yoder AD, Malhi RS, Perry GH (2014) Comparative and population mitogenomic analyses of Madagascar's extinct, giant 'subfossil' lemurs. Journal of Human Evolution 79: $45-54$.

Knapp M, Clarke AC, Horsburgh KA, Matisoo-Smith EA (2012) Setting the stage- -building and working in an ancient DNA laboratory. Annals of Anatomy-Anatomischer Anzeiger 194: 3-6.

Kon T, Yoshinto T, Mukai T et al (2007) DNA sequences identify numerous cryptic species of vertebrate: a lesson from the gobioid fish Schindleria. Mol Phylogenet Evol 44:53-62.

Lambrides ABJ and Weisler MI (2015) Applications of vertebral morphometrics in Pacific Island archaeological fishing studies. Archaeology in Oceania 50: 43-70.

Lambrides ABJ and Weisler MI (2016) Pacific Islands ichthyoarchaeology: implications for the development of prehistoric fishing studies and global sustainability. Journal of Archaeological research 1-50.

Langley J (2006) Vezo knowledge: traditional ecological knowledge in Andavadoaka, southwest Madagascar. London: Blue Ventures.

Laroche J, Razanoelisoa J, Fauroux E, Rabenevanana MW (1997) The reef fisheries surrounding the south-west coastal cities of Madagascar. Fisheries management and ecology 4: 285-299.

Merrick JR and Schmida GE (1984) Australian freshwater fishes-biology and management. Griffin Press: South Australia.

Mitchell K, Llamas B, Soubrier J, Rawlence NJ, Worthy TH, Wood J, Lee MSY, Cooper A (2014) Ancient DNA reveals elephant birds and kiwi are sister taxa and clarifies ratite bird evolution. Science 344: 898-900.

Murray DC, Pearson SG, Fullagar R, Chase BM, Houston J, Atchison J, White NE, Bellgard MI, Clarke E, Macphail M, Gilbert MTP, Haile J, Bunce M (2012). High-throughput sequencing of ancient plant and mammal DNA preserved in herbivore middens. Quaternary Science Reviews 58: 135-145.

Murray DC, Haile J, Dortch J, White NE, Haouchar D, Bellgard MI, Allcock RJ, Prideaux GJ, Bunce M. 2013. Scrapheap challenge: a novel bulk-bone metabarcoding method to investigate ancient DNA in faunal assemblages. Scientific Reports 3: 3371.

Myers N, Mittermeler RA, Mittermeler CG, da Fonsenca GAB, Kent J (2000) Biodiversity hotspots for conservation priorities. Nature 403: 853-858. 
Nadon MO, Griffiths D, Doherty E, Harris A (2007) The status of coral reefs in the remote region of Andavadoaka, Southwest Madagascar. Western Indian Ocean Journal of Marine Science 6: 207-218.

Nicholls A, Matisoo-Smith E, Allen MS (2003) A novel application of molecular techniuqes to Pacific archaeofish remains. Archaeometry 45: 133-147.

Nikulina EA and Schmölcke U (2015) Archaeogenetic evidence for medieval occurrence of Atlantic sturgeon Acipenser oxyrinchus in North Sea. Environmental Archaeology DOI 10.1179/1749631415Y.0000000022.

Orlando L, Calvignac S, Schnebelen C, Douady CJ, Godfrey LR, Hanni C (2008) DNA from extinct giant lemurs links archaeolemurids to extant indriids. BMC Evolutionary Biology 8: 121 .

Pauly D, Christensen V, Dalsgaard J, Froese R, Torres FJ (1998) Fishing down the marine food webs. Science magazine 279.

Rick TC, Kirch PV, Erlandson JM, Fitzpatrick SM (2013) Archaeology, deep history, and the human transformation of island ecosystems. Anthropocene 4: 33-45.

Roy R, Dunn S, Purkis S (2009) Mapping Velondriake: the application of bathymetric and marine habitat mapping to support conservation planning, southwest Madagascar. Blue Ventures Conservation 18.

Schroeder H, Ávila-Arcos M, Malaspinas A, Poznik GD, Sandoval-Velasco M, Carpenter ML, Moreno-Mayar JV, Sikora M, Johnson PLF, Allentoft ME, Samaniego JA, Haviser JB, Dee MW, Stafford Jr TW, Salas A, Orlando L, Willerslev E, Bustamante CD, Gilbert MTP (2015) Genome-wide ancestry of $17^{\text {th }}$-century enslaved Africans from the Caribbean. Proceedings of the National Academy Sciences of the United States of America 112: 3669-3673.

Speller CF, Yang DY, Hayden B (2005) Ancient DNA investigation of prehistoric almon resource utilization at Keatley Creek, British Columbia, Canada. Journal of Archaeological Science 32: 1378-1389.

Speller CF, Hauser L, Lepofsky D, Moore J, Rodrigues AT, Moss ML, McKechnie I, Yang DY (2012) High potential for using DNA from ancient herring bones to inform modern fisheries management and conservation. PLOSOne DOI:10.1371/journal.pone.0051122.

Teletchea F (2009) Molecular identification methods of fish species: reassessment and possible applications. Rev Fish Biol Fisheries 19:265-293.

Wheeler A and Jones AKG (1989) Fishes. Cambridge University Press: Cambridge.

Willerslev E and Cooper A (2005) Ancient DNA. Proceedings of the Royal Society BBiological Sciences 272: 3-16.

Yang D, Cannon A, Saunders S (2004) DNA species identification of archaeological salmon bone from the Pacific Northwest Coast of North America. J Archaeol Sci 31: 619-631. 